Proc. Estonian Acad. Sci. Geol., 2004, 53, 2, 125-138

\title{
Revision of the Ordovician cheirurid trilobite genus Reraspis with the description of the earliest representative
}

\author{
Helje Pärnaste \\ Institute of Geology at Tallinn University of Technology, Estonia pst. 7, 10143 Tallinn, Estonia; \\ helje@gi.ee \\ Received 12 November 2003, in revised form 6 February 2004
}

\begin{abstract}
The morphology of Reraspis Öpik, 1937 is reviewed and compared with other cyrtometopinines. Species previously referred to Reraspis are discussed and the generic composition is revised. Reraspis ranges from the Kunda (lower Middle Ordovician) to the Oandu (middle Upper Ordovician) Stage. It occurs in northern Estonia, Russia, and central Sweden (Dalarna). The earliest representative of the genus is the new species Reraspis orvikui from the Pakri Sandstone of VäikePakri Island, NW Estonia. The genus also includes the type species $R$. plautini (Schmidt, 1881), $R$. latifrons (Warburg, 1925), and possibly $R$. kaljoi Männil, 1958. Specimens from the Keila Stage of Estonia, originally referred to as Ceraurinella? cf. latifrons, are rather similar to R. latifrons and may either prove conspecific or closely related. Hemisphaerocoryphe? rosenthali (Schmidt, 1881) and Reraspis? kaljoi Männil, 1958 share several characters with Reraspis and Cyrtometopella Nikolaisen, 1961, but a safe generic assignment requires better knowledge of the latter genus, especially concerning the pygidia. Reraspis? sexermis Öpik, 1937 is better assigned to Xylabion Lane, 1971. The closely similar X. helgoeyense (Nikolaisen, 1961) may constitute a junior synonym. Remipyga? sp. sensu Männil, 1958, [= Xylabion sp. (Männil)] is also very closely related to Xylabion glaber. All three may in turn prove junior synonyms of Xylabion glaber (Angelin, 1854).
\end{abstract}

Key words: trilobites, taxonomy, Reraspis, Cheiruridae, Cyrtometopinae, Kunda Stage, Llanvirn, Baltic, Estonia.

\section{INTRODUCTION}

East Baltic cheirurids were treated monographically by Schmidt $(1881,1907)$ and Öpik (1937). Öpik discussed some systematic aspects of the cheirurids and erected two cheirurine subfamilies, Cyrtometopinae and Sphaerexochinae, as well as several new genera, including Reraspis (based on Cheirurus (Cyrtometopus) plautini Schmidt, 1881) and Krattaspis (for discussion of subfamily origin, see Pärnaste 2001, 2003). Männil (1958) subsequently described additional cheirurine material and discussed the generic allocation of several taxa (Fig. 1). Ceraurinella? 


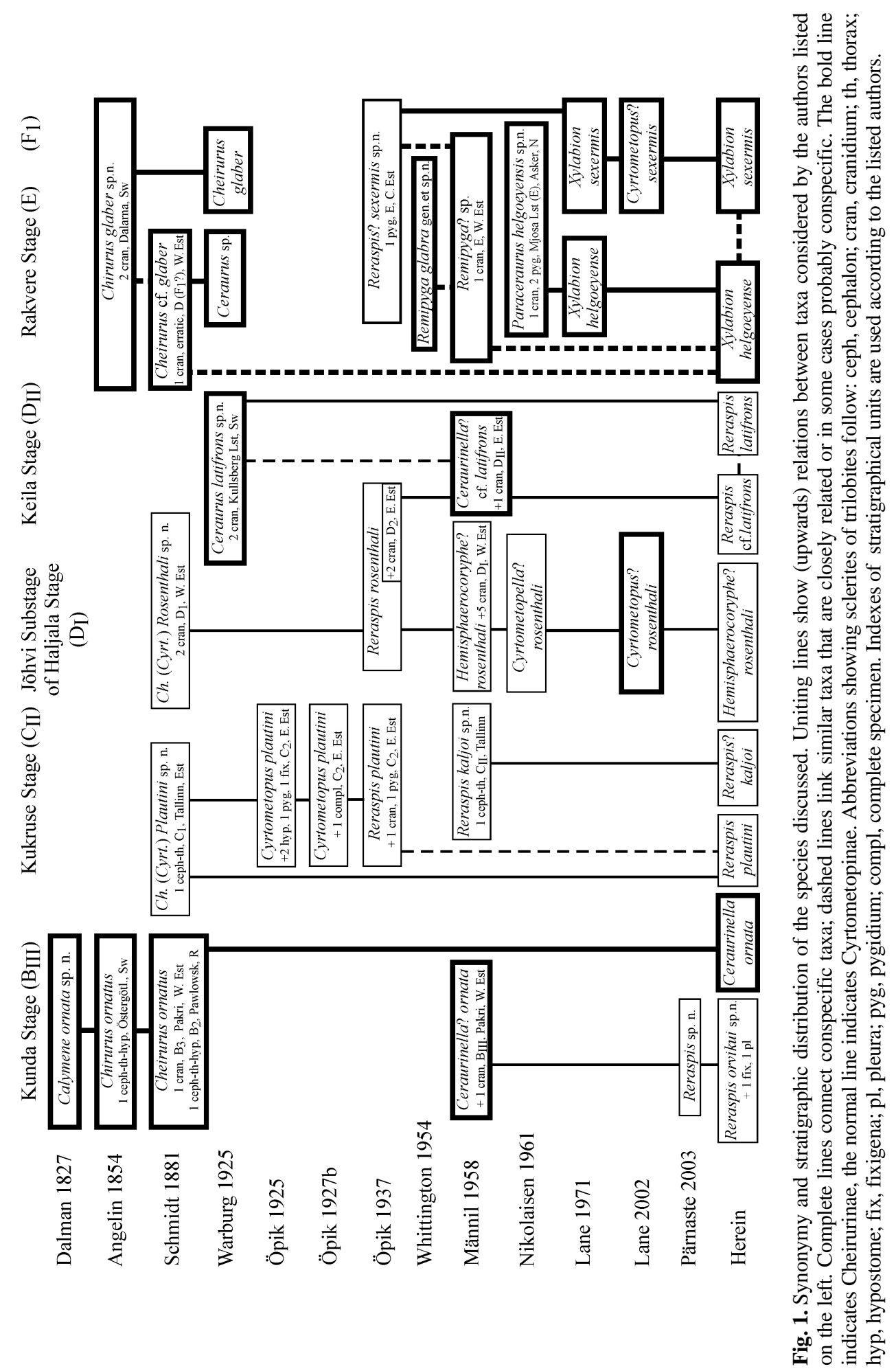


cf. latifrons (Warburg, 1925) was described (ibid., p. 174, pl. 1, figs. 5, 6) from the topmost part of the Keila Stage of Rakvere and Oandu districts, eastern Estonia. Stratigraphically these beds were correlated partly with the Kullsberg Limestone in Dalarna, Sweden, from where the type material of Ceraurus latifrons Warburg (1925) originates. Männil also synonymized a part of Reraspis rosenthali (Schmidt, 1881) sensu Öpik (1937, p. 111, pl. 12, fig. 3; refigured in Männil 1958, pl. 1, fig. 6) with this species, while Schmidt's originals (Schmidt 1881, p. 236, textfig. $15 \mathrm{a}-\mathrm{c}$ ) from Madise [= St. Mathias] and Saue [= Friedrichshof], northwestern Estonia, and a newly discovered specimen (Männil 1958, p. 179, pl. 3, figs. 8, 9) from Pääsküla, Tallinn, Haljala Stage, were considered to belong probably in Hemisphaerocoryphe Reed, 1896. Männil (1958) compared this upper Ordovician C.? cf. latifrons with a much earlier specimen identified as Ceraurinella? ornata (Dalman, 1827) (ibid., p. 174, pl. 3, fig. 10). He also described a cranidium named Remipyga? sp. (1958, p. 175) from the Rakvere Stage at Munalaskme, western Estonia, suggesting that it possibly matches the pygidium of Reraspis? sexermis Öpik, 1937.

The aim of the present study is to describe the earliest representative yet known of the genus Reraspis, to emend the diagnosis of this cyrtometopinine genus and to discuss briefly the related taxa mentioned above. The Estonian material under discussion is housed at the Institute of Geology, Tallinn University of Technology (GIT collection Nos. 103, 153, 360, and 395) and the Institute of Geology, University of Tartu (TUG 1085, Öpik's collection). Terminology follows that of Whittington (1997) with some additions (LM, LA, pre-eye-ridge fixigena) used earlier by the present author (Pärnaste 2003). Apart from where otherwise stated, all dimensions in the sagittal or exsagittal directions refer to length, and all dimensions in the transverse direction refer to width. Measurements are made along the surface of the exoskeleton (see Pärnaste 2003, p. 244, text-fig. 4). Specimens were coated with ammonium chloride before being photographed.

\title{
SYSTEMATIC PALAEONTOLOGY
}

\author{
Suborder CHEIRURINA Harrington \& Leanza, 1957 \\ Family CHEIRURIDAE Hawle \& Corda, 1847 \\ Subfamily CYRTOMETOPINAE Öpik, 1937 (sensu Pärnaste, 2003)
}

Genus Reraspis Öpik, 1937

Type species (by monotypy). Cheirurus (Cyrtometopus) plautini Schmidt, 1881, p. 159, pl. 12, figs. 24a-c; pl. 16, fig. 15 (see also Bruton et al. 1997); redescribed by Öpik (1937, pp. 105-111, text-figs. 27-30, pl. 11, figs. 1-5, pl. 19, fig. 5); from the middle part of the Echinosphaerites Limestone $\left(\mathrm{C}_{1}\right.$ to $\left.\mathrm{C}_{2}\right)$ at Lasnamägi [Laaksberge], Tallinn [Reval], Estonia, i.e. probably the Uhaku or maybe the Kukruse Stage. 
Other species included. R. latifrons (Warburg, 1925), R. orvikui sp. nov. plus perhaps $R$. kaljoi Männil, 1958. The generic assignment of the latter is uncertain because of the unclear status of Cyrtometopella (see below) and the incomplete knowledge about its pygidium.

Emended diagnosis. Cyrtometopinine with subrectangular slightly expanding glabella, possessing broad, relatively low trapezoidal anterior lobe (LA); medially it slopes down together with the anterior border. The long relatively large eyes are positioned close to the lateral border. The preglabellar furrow is relatively shallow and narrow, becoming weaker medially. The lateral glabellar furrows are well impressed, S1 joins the occipital furrow bounding relatively large elongated (exsag.) subquadrate L1 lobe. The palpebral furrow is prominent and delimits the eye-ridge posteriorly, dying out shortly adaxially, also joining a shallow posterior sutural furrow (indicated by row of pits). Librigenal field is reduced, eye-socle reaches the lateral border. The genal angle ends in a pointed tip or in a very short spine. The parallel-sided (tr.) occipital ring carries a small occipital tubercle. Thorax has ten segments and pygidium three, ending in short spines.

Comparison. Reraspis was originally separated from Cyrtometopus Angelin, 1854 by its reduced number of thoracic segments, in this respect resembling the Eccoptochile scuticauda-group as pointed out by Öpik (1937, p. 106). However, the last group has a row of pits on the thoracic pleurae instead of a continuous furrow and probably belongs to a different subfamily (Lane 1971) or even family (Pärnaste 2001). Although a complete specimen of Reraspis plautini figured by Öpik (1927b, pl. 4, fig. 2; 1937, pl. 9, figs. 1-3) actually shows some interruption of the lines alternating with pits similar to Morse code ["Morsezeichen"] (Öpik 1937, p. 106), this pattern is an exception. The interruption seems to be an abnormality or a preservational artefact as it can be traced only on a few pleurae. Other features mentioned to be characteristic of Reraspis are the anteriorly expanding rather wide glabella, and the deep well-incised lateral glabellar furrows (Öpik 1937, p. 106), while Cyrtometopus possesses an elliptical glabella with less prominent $\mathrm{S} 2$ and $\mathrm{S} 3$ furrows.

Reraspis resembles Krattaspis by having an only slightly expanding glabella with relatively short anterior lobe covered by coarse tubercles. It differs inter alia by its lower lateral lobes with parallel S2 and S3 and the anterior lobe evenly flattening and tapering anteriorly. Fixigenae are smaller, with the eyes spaced farther apart, close to the border and delimited by distinct palpebral furrows (for additional differences, see Pärnaste 2003, p. 247).

Sphaerocoryphe Angelin, 1854 and Hemisphaerocoryphe Reed, 1896, which according to some authors probably represent only one genus (Lane 1971; Holloway \& Campbell 1974; Tripp et al. 1997), have a characteristic bulbous glabella different from the above mentioned genera. Sphaerocoryphe has several apomorphies, including the additional profixigenal spine(s) on the lateral border of the fixed cheek (Chatterton 1980; Tripp et al. 1997), the glabellar S3 and S2 apodemes reduced to a low knob in the axial furrow (seen ventrally), with no 
furrows continuing adaxially onto the glabella on the dorsal side, the thorax with fewer segments (nine) but the additional preanterior pair of pleurae on the pygidium being remnant from the juvenile thorax, and the inner two pairs of pleurae reduced but the additional pair developed on the ventral side of the pygidium. I doubt therefore that it should be amalgamated with Hemisphaerocoryphe, even on the subgeneric level suggested by Zhou et al. (1998), and followed by Chen \& Zhou (2002).

The Bohemian Actinopeltis Hawle \& Corda, 1847 has rather short pygidial spines similar to those of Reraspis, but the number of thoracic segments is smaller whereas the number of pygidial segments is higher.

The only known pygidium of Reraspis, that of the type species, is rather Cheirurus-like, sharing the same short anteriormost pleural spines. However, the pattern of the pygidial apodemes and construction of the fulcrum are different.

Occurrence. The earliest known representative of Reraspis, $R$. orvikui sp. nov. appears in the Kunda Stage of eastern Baltoscandia, which matches a level slightly above the base of the Darriwilian International Stage. Some as yet undescribed specimens have been found at the Uhaku level (latest Llanvirn) in the Krapivno drill core, Leningrad District, (assessed by Ralf Männil; GIT 153). Reraspis is relatively rare in the Kukruse Stage (Lower Caradoc) of Estonia, forming about $3 \%$ of the trilobite fauna (Pärnaste unpubl., GIT 360), although, it still is the best known species of Reraspis as around 60 specimens have been recovered. The only known specimen of coeval R? kaljoi (Männil 1958, p. 179, pl. 3, figs. 6, 7) comes from the vicinity of Tallinn. Reraspis is very rare in younger beds, where only a few specimens are known up to the Keila Stage (middle Caradoc) in Estonia. In central Sweden R. latifrons (Warburg, 1925) appears in the coeval Kullsberg Limestone (Fig. 1).

Reraspis orvikui sp. nov.

Plate I

1958 Ceraurinella? ornata (Dalman, 1827); Männil, p. 174, pl. III, fig. 10

2003 Reraspis sp. nov.; Pärnaste, p. 247

Derivation of name. In honour of the well-known Estonian geologist Professor Karl Orviku, who made a major contribution to the investigation of the Ordovician of Estonia. He is also the collector of the holotype cranidium.

Holotype. Cranidium [GIT 103-53 (= Tr 1899 in previous numbering)], earlier illustrated by Männil (1958, pl. III, fig. 10). The specimen is slightly distorted and obviously somewhat compacted. Paratype: Fragmentary cranidium (GIT 395-3) on the same slab as holotype. The sample originates from Väike-Pakri Island, northwestern Estonia; the precise locality is uncertain because the original label is lost. The stratigraphical horizon of the type specimens is discussed below. 


\section{PLATE I}
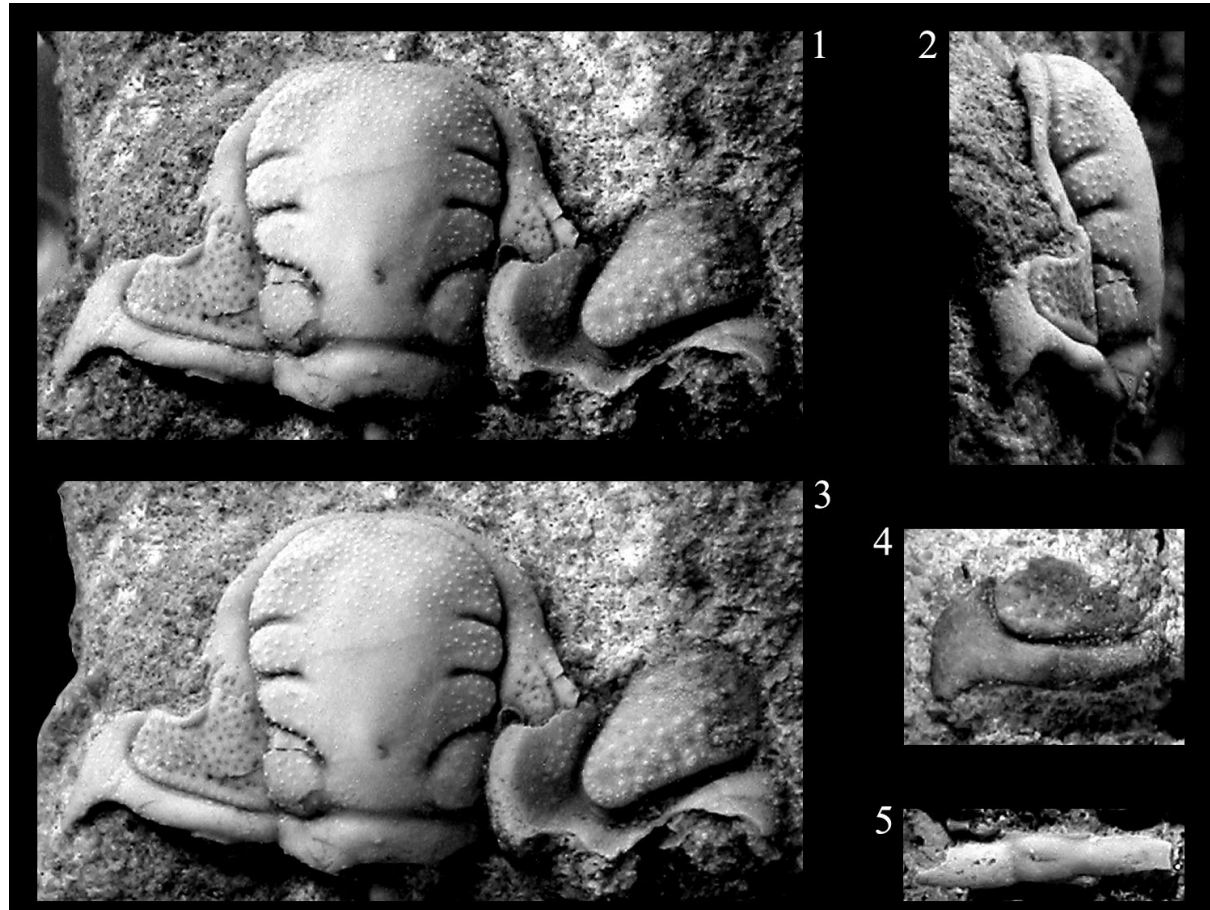

6
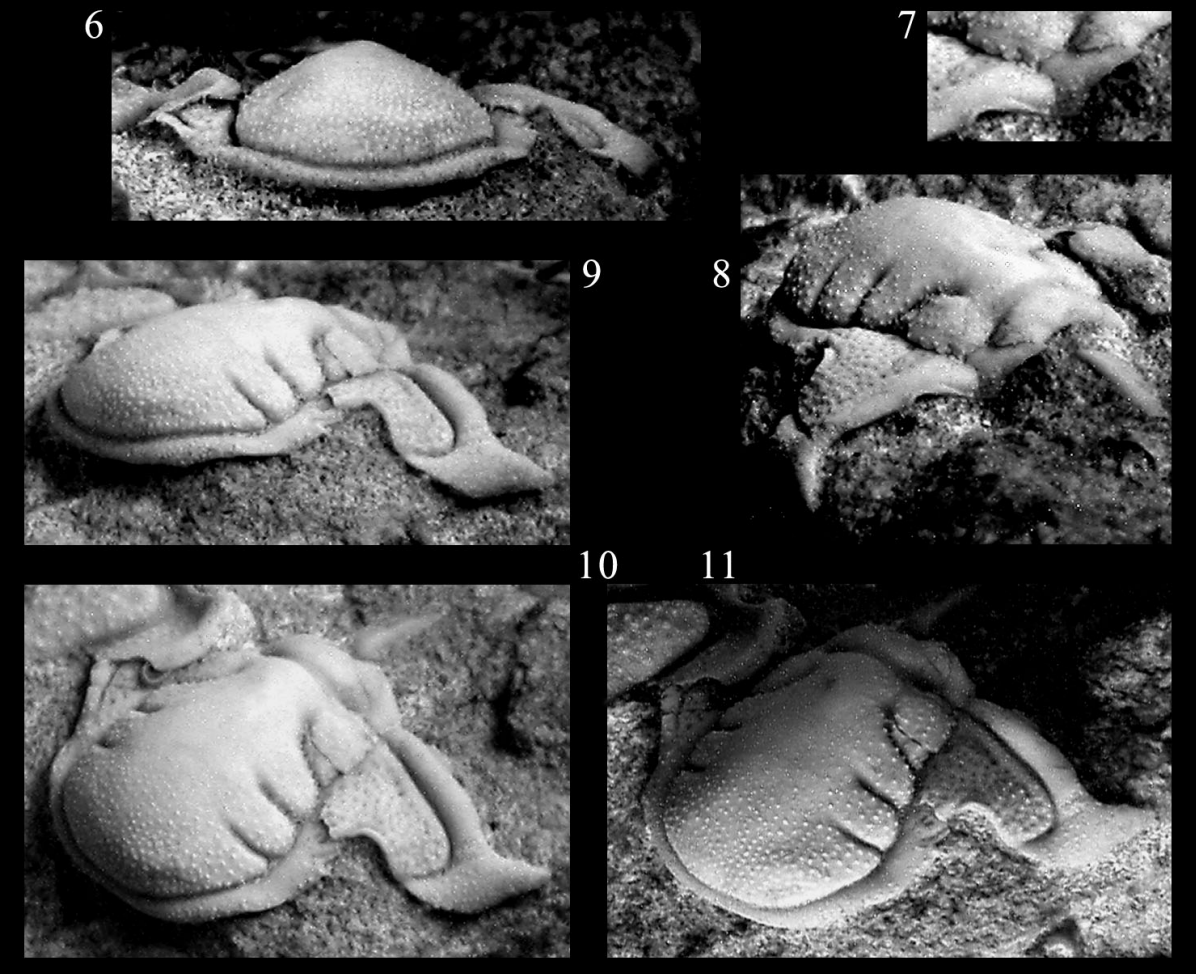

$10 \quad 11$

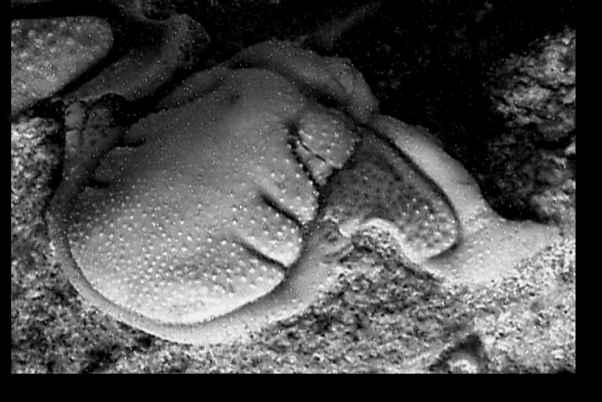


Other material. A posterior fixigena with genal spine (GIT 395-1) and a thoracic pleura (GIT 395-2) collected by the author in 2003 from sandy layers in the upper part of the Pakri Formation on the Pakri Peninsula. The specimens were collected from loose boulders, but the distinctive lithology shows that they derive from a level about $40 \mathrm{~cm}$ below the top of the Pakri Formation.

Diagnosis. Reraspis with nearly parallel-sided low glabella possessing slightly expanding LM, long basal lobe and relatively long identical, distinct S2 and S3 furrows directed parallel to each other. Eyes situated relatively close to the glabella, delimited by palpebral furrows running roughly parallel to axis. Hence, the palpebral and anterior fixigena are narrow. The posterolateral fixigena is relatively long and only slightly curving down abaxially. The anterior border is gently convex (sag., exsag.) and of the same length throughout except for a slight elongation at the junction of the anterior and rostral sutures.

Description. Cephalon semi-oval in outline, longer than wide, only slightly convex (sag., tr.), with short genal spines and apparently small free cheeks (unknown). The large glabella occupies $38 \%$ of the width of cephalon at the basal lobes. The width of the glabella at basal lobes is $80 \%$ of its sagittal length. The glabella expands only $10 \%$ from LO to L3, it is moderately inflated and conical in crosssection (tr.). The occipital ring is nearly parallel-sided (tr.), except behind the basal lobes (note, it is somewhat distorted on holotype), and carries a small median tubercle. The occipital furrow curves adaxially forward to meet S1, giving a trapezoidal shape to LO. L3 is nearly equal to L2 and LO, but L1 is twice as long and leaf-like in shape, getting narrower anteriorly when meeting the axial furrow. LA occupies $40 \%$ of the sagittal glabellar length, also bending slightly down anteriorly. The lateral glabellar lobes have a faint independent convexity. Moderately deep S2 and S3 furrows arch slightly rearwards, shallowing rapidly in their adaxial ends; equally S1 curves strongly to meet SO, shallowing visibly from the middle of the basal lobe. The axial furrow is deep but relatively narrow, although this can be a result of compaction. The anterior border furrow is shallower and less distinct, whereas the occipital furrow is much broader.

The equilateral fixigena is nearly horizontal adaxially from the eyes, but slopes gently down posterolaterally. The test surface between the eye-ridge and the

\section{Explanation of Plate I}

Figs. 1-11. Reraspis orvikui sp. nov. 1-3, 6-11, somewhat distorted and testiferous holotype cranidium (GIT 103-53) collected by Karl Orviku from the Pakri Formation, Väike-Pakri Island, northeastern Estonia. 1, 2, dorsal and side views of the specimen oriented with posterior glabella horizontal; 3, dorsal view oriented with posterior fixigena horizontal; 6 , anterior view; 7, 8, posterior oblique view, 7, the enlargement of fig. 8 to show the fulcral process and the apodeme at the articulating flange; 9-11, different oblique views with different angles of lighting; all $\times 4$, except $7 \times 6.5$. 4, posterior fixigena possessing genal spine (GIT 395-1) in dorsal view, collected by the author from the Pakri Formation, Pakri Peninsula, $\times 4$. 5, thoracic pleura (GIT 395-2) in dorsal view, collected by the author on the Pakri Peninsula $\times 5$. 
posterior border is covered by small, deep pits. The pits outline a posterior sutural ridge that is fused with the palpebral lobe, and also a ridge ahead of the posterior border furrow. The anterior fixigena comprises a barely discernible in relief wide and low eye-ridge. Only one small pit close to the suture possesses the reduced preeye-ridge fixigena (for terminology, see Pärnaste 2003). The horizontal palpebral lobe, which levels with the fixigena, is relatively narrow and low, and midway shows one muscle-scar (a pit within the dark patch) (cf. Størmer 1980, p. 266, pl. 33, fig. 3) close to the edge (note, the left palpebral lobe is broken on holotype).

The posterior border is almost as long as LO adaxially, but tapers slowly towards the fulcrum, then regains the previous length (exsag.) and stays so to the genal angle. The lateral border is twice as broad as the posterior border at the genal angle. Genal spine is short, actually as short as the posterior fixigena. The convex anterior border of the cranidium is relatively constricted and narrows medially. The anterior border furrow is shallow and broad, being also slightly convex (tr.). Anterior suture meets the rostral suture opposite the mid-width of the lateral lobes of the glabella, so that the rostral plate is rather wide. The downward curvature of the anterior border laterally of it and that of the anterior fixigena is weak, so the librigena must be quite horizontal. The test surface of both the glabella and the fixigenal field is covered by sparse small tubercles, whereas faint granules are seen on the borders.

A fragmentary thoracic pleura (Pl. I, fig. 5) shows a slightly arching axial ring, bearing a moderate articulating furrow extending abaxially into a deep sigmoidal (tr.) apodemal pit. The articulating half-ring has about the same sagittal length as the articulating furrow, together representing about one-third the length of the axial ring. The axial furrow is narrow but distinct. The inner portion of the pleura is shorter (tr.) than the free spine. It is divided by a sharp and narrow transverse pleural furrow into equal-sized anterior and posterior bands that are slightly inflated. In general, the pleural furrow runs parallel to the sides of the thoracic segment, becoming effaced at the fulcrum. However, it is slightly curved anteriorly at its adaxial end, as also described for Cyrtometopus (Lane 1971, p. 9; 2002, p. 162) and Krattaspis (Pärnaste 2003, p. 252). The pleural spine shows a low "knee" at its base, smoothly merging with the flattened spine showing convex edges. The spine curves gently rearwards distally and slopes downwards just a few degrees.

Comparison. The new species co-occurs with the cheirurinine Ceraurinella ornata (Dalman, 1827) (GIT unpubl. material; see also Schmidt 1881, p. 135, pl. 16, fig. 1; listed in Öpik 1927a, pp. 52, 53). These species are, however, readily separated since $C$. ornata has a parallel-sided glabella with lateral lobes showing no independent inflation. Also the basal lobe of $C$. ornata is entirely separated by evenly deep S1, and the anterior fixigena and anterior border are very narrow. The anterior border furrow between them is well developed and meets the anterolateral corner of the glabella somewhat ahead of the point, where S3 joins the axial furrow, as in all cheirurinines. Unlike as in Reraspis orvikui sp. nov., the exoskeleton of $C$. ornata is smooth with no distinct granulation. 
Reraspis orvikui differs from the type species R. plautini (Schmidt 1881, p. 159 , pl. 12, figs. 24a-c; pl. 16, fig. 15; Öpik 1925, pl. 1, figs. 5, 6; Öpik 1927b, p. 25 , pl. 4, fig. 2 ; Öpik 1937, pp. 105-111, text-figs. 27-30, pl. 11, figs. $1-5$, pl. 19, fig. 5) in its generally flatter image, evidently longer (tr.) lateral glabellar furrows S2, S3, and longer (exsag.) basal lobes, as well the eyes are situated closer to the glabella. The last character is shared with R.? kaljoi (see Männil 1958 , p. 179 , pl. 3 , figs. 6,7 ) but the latter is very much inflated resembling so Cyrtometopella.

Schmidt (1881, p. 236, text-fig. 15a-c) differentiated Cheirurus (Cyrtometopus) rosenthali from $C$. $(C$.) pseudohemicranium (Nieszkowski, 1859), both from the Jõhvi Substage [Jewesche Schicht] of the Haljala Stage, emphasizing the genal spine that curves strongly rearwards in combination with the deep lateral glabellar furrows, of which the anteriormost rises up vertically from the axial furrow (see Fig. 1, which summarizes the following review). Öpik (1937) thought that Schmidt's species probably belongs to his new genus Reraspis because of its deep and short lateral glabellar furrows, a convex glabella overhanging the anterior border, and broad palpebral lobes. Both Schmidt and Öpik mentioned that $C$. rosenthali resembles both $C$. pseudohemicranium and $C . / R$. plautini. Männil (1958, p. 179, pl. 3, figs. 8, 9) tentatively assigned C. rosenthali to Hemisphaerocoryphe and noted that the additional specimen (Öpik 1937, pl. 12, fig. 3; refigured by Männil 1958, p. 174, pl. 1, figs. 5, 6), from somewhat younger beds seemingly belongs to Ceraurinella? cf. latifrons (Warburg, 1925). He emphasized the well-developed eye-ridge, running across the anterior fixigena to glabella, and considered as characteristic of the Cheirurinae. On the other hand, the development of the sutural ridge, running to the anterior border, was diagnostic of the Cyrtometopinae. However, the latter condition reflects the narrowness of the anterior fixigena, and the eye-ridge runs towards the glabella in both cases (for discussion of "false eye-ridge", see Pärnaste 2003, p. 244). The fossula of the cyrtometopinines slopes deeply down rearwards into the axial furrow joining the S3 apodeme. That of the cheirurinines curves down forward from the S3 furrow to meet the prefixigenal and the preglabellar furrows somewhat ahead. Consequently, it is evident that latifrons and the specimen figured by Öpik represent the Cyrtometopinae and most closely Reraspis. The Estonian material differs from the type material in its more ancestral characters (similar to R. plautini), such as wider and more trapezoidal LA, more elongate L1, wider anterior fixigena and heavier (denser and larger-sized) tuberculation, and possibly also in attaining bigger maximum size, although it is cautioned that the available material comprises only very few specimens. A more detailed comparison with $R$. latifrons (Warburg) must await description of additional material from the type area Dalarna, Sweden.

The new species is distinguished from $R$. cf. latifrons (Warburg) (see Männil 1958 , p. 174, pl. 1, figs. 5, 6) by its longer and flatter LA, narrower anterior and palpebral fixigena, and thus more adaxially positioned eyes.

Occurrence. The kerogenous more or less calcareous sandstone of the Pakri Formation (Kunda Stage) is about $1.2 \mathrm{~m}$ thick on Väike-Pakri Island (and on the Pakri Peninsula). The slab with the holotype is about $10 \times 10 \times 1 \mathrm{~cm}$ and shows a 
characteristic texture of thin-bedded brownish-grey kerogenous calcareous sandstone rich in pyrite, including a small phosphate pebble on its underside. Four such interbeds divide the Pakri Formation into three parts (see Orviku 1960, fig. 12). It is likely that the holotype originates from the lower part of the formation, where phosphatic pebbles are common. The holotype is associated with a hypostome of Metopolichas sp., two cranidia of Pterygometopus sclerops (Dalman, 1827), and some fragmentary bryozoans, crinoids, brachiopods, and ostracods. The additional material collected by the author originates from the upper part of the Pakri Formation, Pakri Peninsula. The Pakri Formation is generally assumed to represent the Asaphus raniceps (Öpik 1927a, p. 42; Orviku 1960, p. 68, fig. 12) or the Asaphus eichwaldi-Ptychopyge globifrons trilobite Zone (Lamansky 1905, pp. 59, 90, 93, 95), but the exact correlation of these two zones on Väike-Pakri Island is still unclear. The same uncertainty arises with graptolites from the last mentioned locality and horizon. They were first identified as Didymograptus sp. by Öpik (1927a, p. 62, pl. 1, fig. 3) and later as Didymograptus bifidus (Hall, 1865) by Obut (1960, p. 152, pl. 5, figs. 2, 2a). Jaanusson (1960, p. 314) revealed that they represent a new species, Didymograptus pakrianus Jaanusson, 1960, that is similar to both D. (Didymograptellus) "bifidus" and D. (Didymograptus) murchisoni Beck, 1839. He also recorded D. (Didymograptus) cf. artus Elles \& Wood, 1901 from the Pakri Formation on Väike-Pakri Island.

\section{DISCUSSION OF TAXA RELATED TO RERASPIS}

Nikolaisen (1961, p. 288) established Cyrtometopella and proposed to include Cheirurus (Cyrtometopus) rosenthali within it, a suggestion later followed by Bruton et al. (1997, p. 102). Cyrtometopella askerensis Nikolaisen, 1961 from the Caradoc Vollen Formation (= Ampyx Limestone, see Owen et al. 1990) in the Oslo Region is indeed rather similar to rosenthali, sharing deep and short S2 and S3 of an elongate glabella that flattens and narrows anteriorly, still overhanging the anterior border. In these respects both resemble Hemisphaerocoryphe sulcata Thorslund, 1940 and Cyrtometopus? aries (Eichwald, 1843). Moreover, the pygidia identified with askerensis resemble those of Hemisphaerocoryphe, possessing only one pair of pleural spines between the stout anterior pair. However, several apomorphies of the type species, Cyrtometopella tumula Nikolaisen, 1961 from the Vollen Formation and the overlying Arnestad Formation (= Lower Chasmops Shale) in the Oslo Region, are not shared with the above-mentioned group, such as the conical shape of the glabella, the lens-shaped relatively high occipital ring, etc. It is not clear, whether these differences warrant a differentiation at generic or species level. Since no pygidia of the preceding species have been found, the generic position and status of the genus Cyrtometopella stays unclear and likewise the generic status of Hemisphaerocoryphe? rosenthali. Alternatively, rosenthali and aries may also belong in Cyrtometopus (Schmidt 1881; Lane 2002, p. 164).

Lane (1971, p. 41) ascribed Reraspis? sexermis (Öpik 1937, p. 112, pl. 12, fig. 4), to Xylabion based on a pygidium from the Rakvere Stage (at Voore, 
Central Estonia), but subsequently he included it in Cyrtometopus (Lane 2002, p. 165). I support Lane's original assignment, because sexermis shows several cheirurinine features including a characteristic morphology of the first pleural lobe, the apodemes, and the fulcrum. The first pleural furrow is deeply incised and the anterior half of the pleural lobe is distinctively bulbous, also a "knee" appears at the base of the spine near the fulcrum. Xylabion helgoeyense (Nikolaisen, 1961) from the Mjøsa Limestone, Helgøya, Oslo Region, closely resembles sexermis and probably represents a junior synonym. However, Xylabion helgoeyense differs from $X$. sexermis in possessing a slightly narrower pleural field (for terminology, see Pärnaste 2003, p. 244, text-fig. 4B-a) and posterior border (ibid., text-fig. 4B-e), and also in having a somewhat broader axis with a narrower terminal knob.

A cranidium referred to as Remipyga? sp. by Männil (1958, p. 175, pl. 3, fig. 11) from the Rakvere Stage at Munalaskme, western Estonia, is very similar to that of $X$. helgoeyense. It differs from the last, a specimen half its size, in a wider middle lobe of the glabella, which is also slightly more arched (tr.), and the eyes situated farther abaxially. As little is known of the growth variation of the species, it is difficult to assess exactly whether they are conspecific. However, most likely the cranidium of Remipyga? sp. Männil belongs with the coeval pygidium of X. sexermis (Männil 1958, p. 175), which in turn is very similar to that of $X$. helgoyense (see above). Remipyga Whittington, 1954 was synonymized with Ceraurinus Barton, 1913 by Ludvigsen (1977) after finding more complete material of type species of the latter. Xylabion Lane, 1971 is also very similar to Ceraurinus, and therefore generic validation of all these three should be tested by cladistic analysis together within all cheirurinine genera. If it reveals that Xylabion is not valid on a generic rank, Ceraurinus glaber (Whittington, 1954) may appear to be a secondary homonym of Chirurus glaber Angelin, 1854, at least considering Schmidt's opinion about the Estonian material being probably conspecific with the Swedish (Schmidt 1881, p. 151).

The cranidium of Cheirurus cf. glaber Angelin, 1854 sensu Schmidt (1881, pl. 7, figs. 18, 18b) found in loose boulders on Hiiumaa Island, western Estonia, is closely related to Remipyga? sp. of Männil. It may prove that all these taxa (see Fig. 1) just represent Chirurus glaber Angelin, 1854 (Fig. 1). Angelin's drawing (Angelin 1854, pl.39, fig. 16) shows a parallel-sided glabella, with deep lateral furrows and L1 subquadratic, as is seen on Ceraurinus, Remipyga, Xylabion, as well as on Schmidt's specimen (1881, pl. 7, fig. 18). Warburg's drawing (1925, pl. 9, figs. 12, 13) shows slight expansion of the glabella resembling Hadromeros Lane, 1971 or Ceraurinella Cooper, 1953. But, from Warburg's description, it has a rounded anterior border effacing medially and the glabella expanding anteriorly and displaying subtriangular basal lobes, which indicates that it may belong in Hadromeros. However, a resemblance to Ceraurinella is also indicated as S2 is shorter than S3, the genal spines are relatively long, and S1 was reported to be running from axial furrows obliquely inwards and backwards a little more than half-way to median line of glabella, then bending more strongly backwards and continuing as shallow grooves to occipital furrow, suggesting it could be also subquadratic. 


\section{ACKNOWLEDGEMENTS}

I am grateful to Dr. Arne T. Nielsen for correcting an early version of this manuscript. Professor Jan Bergström is thanked for kindly showing me the cheirurid Ceraurinella ornata and Paraceraurus? ingricus collections at the Swedish Museum of Natural History and sharing his notes about Angelin's type specimens. I thank reviewers Dr. Madis Rubel, and especially Dr. Alan W. Owen for detailed corrections and helpful comments on the final version of the paper. Financial support of the Estonian Science Foundation (grants Nos. ETF4674 and 5922) is acknowledged.

\section{REFERENCES}

Angelin, N. P. 1854. Palaeontologia Scandinavica I. Crustacea formationis transitionis, 2. Sansom and Wallin, Lund, 21-92.

Barton, D. C. 1913. A new genus of Cheirurinae, with description of some new species. Bull. Mus. Comparative Zoology, 54, 547-556.

Beck, H. H. 1839. In Murchison, R. I. The Silurian System, q.v., Murray, London.

Bruton, D. L., Hoel, O. A., Beyene, L. T. \& Ivantsov, A. Yu. 1997. Catalogue of the trilobites figured in Friedrich Schmidt's "Revision der ostbaltischen silurischen Trilobiten" (1881-1907). Contrib. Palaeont. Mus., Univ. Oslo, 403.

Chatterton, B. D. E. 1980. Ontogenetic studies of Middle Ordovician trilobites from the Esbataottine Formation, Mackenzie Mountains, Canada. Palaeontographica, Abt. A, 171.

Chen, R. \& Zhou, Z. 2002. An Ordovician (Early Llanvirn) trilobite faunule from Nanzheng, southern Shaanxi. Acta Palaeont. Sinica, 41, 219-231.

Cooper, B. N. 1953. Trilobite of the Lower Champlainian Formations of the Appalachian Valley. Geol. Soc. Amer., Mem., 55, 1-69, pls. 1-19.

Dalman, J. W. 1827. Om Palaeaderna, eller de så kallade Trilobiterna. Kungl. Svenska Vetensk. Handlingar, [for 1826] (2), 113-152, 226-294, pls. 1-6.

Eichwald, E. 1843. Neue Beitrag zur Geognosie Estlands und Finlands. Beitrag zur Kenntnis des Russisches Reichs, 8, 1-138, pls. 1-3.

Elles, G. L. \& Wood, E. M. R. 1901. A monograph of British graptolites. Part 1. Monograph Palaeontogr. Soc., (part of $\mathbf{5 5}$ for 1901), 1-54, pls. 1-4.

Hall, J. 1865. Graptolites of the Quebec Group. Geological Survey of Canada, Canadian organic remains, dec. 2, 1-151, pls. A and B, 1-21.

Harrington, H. J. \& Leanza, A. F. 1957. Ordovician Trilobites of Argentina. Department of Geology, University of Kansas, Special Publication.

Hawle, I. \& Corda, A. J. C. 1847. Prodrom einer Monographie der böhmischen Trilobiten. J. C. Calve, Prague.

Holloway, D. J. \& Campbell, K. S. W. 1974. The Silurian trilobite Onycopyge Woodward. Palaeontology, 17, 409-421.

Jaanusson, V. 1960. Graptoloids from the Ontikan and Viruan (Ordovician) limestones of Estonia and Sweden. Bull. Geol. Inst. Univ. Uppsala, 38, 289-366.

Lamansky, V. V. 1905. Die aeltesten silurischen Schichten Russlands (Etage B). Mém. Comité Géol., Nouv. Sér. Livraison, 20, 1-203, pls. 1-2.

Lane, P. D. 1971. British Ordovician Cheiruridae (Trilobita). Monogr. Palaeontogr. Soc., 125.

Lane, P. D. 2002. The taxonomic position and coaptative structures of the Lower Ordovician trilobite Cyrtometopus. Spec. Pap. Palaeontol., 67, 153-169. 
Ludvigsen, R. 1977. The Ordovician trilobite Ceraurinus Barton in North America. J. Paleont., 51, 959-972.

Männil, R. 1958. Trilobites of the families Cheiruridae and Encrinuridae from Estonia. ENSV TA Geol. Inst. Uurimused, 3, 165-212 (in Russian).

Nieszkowski, J. 1859. Zusätze zur Monographie der Trilobiten der Ostsee-provinzen, nebst der Beschreibung einige neuen obersilurischen Crustaceen. Arch. Naturk. Liv-, Ehst- und Kurlands, erster Ser., 2, 345-384, pls. 1-2.

Nikolaisen, F. 1961. The Middle Ordovician of the Oslo Region, Norway, 7. Trilobites of the suborder Cheirurina. Norsk Geol. Tidsskr., 41, 279-310.

Obut, A. 1960. Correlation on some parts of Estonian Ordovician and Silurian deposits according to graptolites. ENSV TA Geol. Inst. Uurimused, 5, 143-158 (in Russian).

Öpik, A. A. 1925. Beiträge zur Kenntnis der Kukruse- (C2-) Stufe in Eesti, I. Acta Comment. Univ. Dorpatensis, A, 8 (5), 1-18, pls. 1-2.

Öpik, A. A. 1927a. Die Inseln Odensholm und Rogö. Ein Beiträg zur Geologie von NW-Estland. Publ. Geol. Inst. Tartu Univ., 9, 1-69. pl. 1, figs. 1-7.

Öpik, A. A. 1927b. Beiträge zur Kenntnis der Kukruse- $\left(\mathrm{C}_{2^{-}} \mathrm{C}_{3^{-}}\right)$Stufe in Eesti, II. Acta Comment. Univ. Dorpatensis, A, 12 (3), 1-35, pls. 1-6; [reprinted in Publ. Geol. Inst. Tartu Univ., 10, $1-35$, pls. 1-6].

Öpik, A. A. 1937. Trilobiten aus Estland. Acta Comment. Univ. Tartuensis, A, 32 (3), 1-163, pls. 1-26.

Orviku, K. 1960. Über die lithostratigraphie der Wolkhow- und der Kunda-Stufe in Estland. ENSV TA Geol. Inst. Uurimused, 5, 45-87 (in Russian).

Owen, A. W., Bruton, D. L., Bockelie, J. F. \& Bockelie, T. 1990. The Ordovician successions of the Oslo Region, Norway. Norges Geol. Unders. Spec. Publ., 4, 1-54.

Pärnaste, H. 2001. On the systematic position of cyrtometopinine (Cheiruridae) trilobites. In Third International Conference on Trilobites and their Relatives, Oxford, April 2001, Abstracts, pp. 24-25.

Pärnaste, H. 2003. The Lower Ordovician trilobite Krattaspis: the earliest cyrtometopinid (Cheiruridae) from the Arenig of the east Baltic. Spec. Pap. Palaeont., 70, 241-257.

Reed, F. R. C. 1896. Notes on the evolution of the genus Cheirurus. Geol. Mag. (New Ser. 4), 3, 117-123, 161-167.

Schmidt, F. 1881. Revision der ostbaltischen Trilobiten. Abtheilung I: Phacopiden, Cheiruriden und Encrinuriden. Mém. Acad. Impér. Sci. St-Pétersbourg (7), 30 (1), 1-237, pls. 1-16.

Schmidt, F. 1907. Revision der ostbaltischen Trilobiten. Abtheilung VI: Allgemeine Übersicht mit Nachträgen und Verbesserungen. Mém. Acad. Impér. Sci. St-Pétersbourg (8), 20 (8), 1-104, pls. $1-3$.

Størmer, L. 1980. Sculpture and microstructure of the exoskeleton in chasmopinid and phacopid trilobites. Palaeontology, 23, 237-271.

Thorslund, P. 1940. On the Chasmops Series of Jemtland and Södermanland (Tvären). Sver. Geol. Unders., Afhandl. Uppsatser, C, 436, 1-191, pls. 1-15.

Tripp, R. P., Rudkin, D. M \& Evitt, W. R. 1997. Silicified trilobites of the genus Sphaerocoryphe from the Middle Ordovician of Virginia. Canadian J. Earth Sci., 34, 770-788.

Warburg, E. 1925. The trilobites of the Leptaena Limestone in Dalarna. Bull. Geol. Inst. Univ. Uppsala, 17, 1-446.

Whittington, H. B. 1954. Ordovician trilobites from Silliman's Fossil Mount. In The Ordovician Cephalopod Fauna of Buffin Island (Youngquist, W. \& Collinson, C., eds.). Geol. Soc. Amer. Mem., 62, i-vii, 1-234, pls. 1-63.

Whittington, H. B. 1997. Morphology of the exoskeleton. In Treatise on Invertebrate Paleontology, Pt. O, Arthropoda I, Trilobita, Revised (Kaesler, R. L., ed.), pp. 1-86. Geological Society of America, Boulder, and University of Kansas Press, Lawrence.

Zhou, Z., Dean, W. T., Yuan, W. \& Zhou, T. 1998. Ordovician trilobites from the Dawangou Formation, Kalpin, Xinjiang, North-west China. Palaeontology, 41, 693-735. 


\title{
Ordoviitsiumi cheiruriidse trilobiidiperekonna Reraspis revisjon koos selle varajasima esindaja kirjeldusega
}

\author{
Helje Pärnaste
}

Artiklis on vaatluse alla võetud A. Öpiku poolt 1937. aastal püstitatud Cheiruridae sugukonda ja Cyrtometopinae alamsugukonda kuuluva perekonna Reraspis tunnused ja liigiline koosseis. Perekonna vanimaks esindajaks osutub varem Ralf Männili poolt alamsugukonna Cheirurinae esindaja Ceraurinella ornata'na kirjeldatud eksemplar, mis on kogutud Kunda-vanuselisest Pakri lubiliivakivist Väike-Pakri saarelt ja on siin kirjeldatud kui uus liik Reraspis orvikui. Antud perekond levib Balti Paleobasseinis kuni Oandu eani, olles teiste trilobiitidega võrreldes suhteliselt harva esinev. Lisaks tüüpliigile $R$. plautini ja eelmainitud uuele liigile kuulub sellesse perekonda veel $R$. latifrons ja tõenäoliselt ka $R$.? kaljoi. Viimane sarnaneb mõneti ka perekond Cyrtometopella esindajatega, mis jätab perekondliku määratluse kaheldavaks. Perekondliku kuuluvuse saab anda alles pärast mõlema taksoni sabakilpide leidmist ja omavahelist võrdlust. Varem korduvalt Reraspis'te hulka loetud liik sexermis kuulub aga pigem perekonda Xylabion alamsugukonnast Cheirurinae, olles väga sarnane Norrast kirjeldatud $X$. helgoeyense'ga, mis võib osutuda ka esimese nooremaks sünonüümiks. Viimastele on omakorda väga sarnased Eestist kirjeldatud Remipyga? sp. ja tuntud Chirurus glaber. Neist esimene tuleks samuti perekonda Xylabion kuuluvaks lugeda, võib-olla ka teine, kuid selle selgitab välja põhjalik uurimus vajalikest tüüpmaterjalidest. 